ZOOLOGIA 32 (6): 463-468, December 2015

http://dx.doi.org/10.1590/S1984-46702015000600005

\title{
Population dynamics of Megalobulimus paranaguensis (Gastropoda: Pulmonata) in the southeast coast of Brazil
}

\author{
Marcel S. Miranda ${ }^{1, *} \&$ José H. Fontenelle ${ }^{2}$ \\ 'Departamento de Biologia Animal, Universidade Estadual de Campinas. Rua Monteiro Lobato 255, 13083-970 Campinas, \\ $S P$, Brazil. \\ ${ }^{2}$ Parque Zoobotânico Orquidário Municipal de Santos. Praça Washington, 11065-600 Santos, SP, Brazil. \\ "Corresponding author. E-mail: marcelsmiranda@gmail.com
}

\begin{abstract}
The population dynamics of Megalobulimus paranaguensis (Pilsbry \& Ihering, 1900), a large and long-lived land gastropod from Brazil's Southeast (Atlantic Forest) was studied between 2006 and 2009, at an urban park in the city of Santos, state of São Paulo. The study included biometry, weighing, and marking and recapture of adult individuals. The variables obtained from specimens were correlated with the environmental variables of the study period. The survival rate of the adult snail population was $96.7 \%$. Recruitment showed several peaks during the year, and was concentrated between April and August, except in 2009, when there was only one peak in August. Specimen abundance progressively increased from 2006 on, with a trend towards relative stability during that period. The condition factor remained relatively stable as well, decreasing from December to February. The potential evapotranspiration and precipitation influenced the number of captures, and the mean temperature influenced the condition factor. Megalobulimus paranaguensis goes through a period of dormancy in the tropical summer, which is between November and February, but remains active in the winter. The survival rate of M. paranaguensis was high, and may be the result of having its annual cycle synchronized with the tropical climate of the Atlantic forest.
\end{abstract}

KEY WORDS. Activity; abundance; dormancy; land snail.

Megalobulimus Miller, 1878, which includes species popularly known as aruá-do-mato, is a group of Neotropical giant snails of Megalobuliminae. Not much is known about the biology, behavior and ecology of species of Megalobulimus and other Brazilian terrestrial gastropods. Megalobulimus spp. populations tend to occur in low densities (EsTon et al. 2006) and, like other native species of terrestrial mollusks, they have low reproductive potential, spawning only two to five eggs per batch (Sobreira \& Molina 2002). They are herbivorous, go through a dormancy period, and bury themselves in the rainforest soil or leaf litter during the day (BEQUAERT 1948). Individuals of Megalobulimus spp. also have a long lifespan (Fontenelle \& Miranda 2012). Since species of this genus are not commonly found, their population dynamics remains poorly understood. Morphologically, species of Megalobulimus are distinguished by having large thick and round shells with vertical nepionic riblets, thickened outer lip in adults (BEQUAERT 1948) and buccal fringe (Leme 1973).

Megalobulimus paranaguensis (Pilsbry \& Ihering, 1900), the subject of this study, has a mean shell length of $98 \mathrm{~mm}$. This species is distributed in the North of the state of Santa Catarina, Paraná and in the south of the state of São Paulo (Morretes 1954, Simone 2006, Agudo-Padron 2014). Currently, the northernmost site from its original distribution is the Is- land of São Vicente. Little is known about the possible reasons that led to this range expansion. Recently, Fontenelle \& Miranda (2012) analyzed the age and growth of M. paranaguennsis and Miranda et al. (2015) analyzed the population structure of the species in the presence of the invasive Achatina fulica Bowdich, 1822 , and pointed out that long-term studies need to be conducted to better understand the population cycles of the species. The aim of this study was to analyze the population dynamics of $M$. paranaguensis from Santos during four years (2006-2009).

\section{MATERIAL AND METHODS}

The study took place from 2006 to 2009 , in the Parque Zoobotânico Orquidário Municipal de Santos (PZOMS) (UTM: 23K E 362672.57, 7348904.53 N), an urban park located in the municipality of Santos, Island of São Vicente, state of São Paulo. The park is surrounded by buildings. Specimens of $M$. paranaguensis were collected within the boundaries of the PZOMS, Monday through Friday, from 7:00 am to 8:00 am, totaling 800 collecting hours in four years. The specimens were marked using Fontenelle \& Miranda (2012) code tags. The total length and weight of specimens were recorded and then specimens were released. Only adult individuals identified by thicker

2015 | Sociedade Brasileira de Zoologia | www.sbzoologia.org.br | www.scielo.br/zool All content of the journal, except where identified, is licensed under a Creative Commons attribution-type BY. 
shell were marked. Voucher specimens of the population studied are deposited in mollusk collection of Museu de Zoologia da Universidade de São Paulo (lot MZSP 54629). The following environmental variables were obtained from the website http:/ /www.ciiagro.sp.gov.br/ciiagroonline/\#Monitoramento (mainatined by EMBRAPA - Agronomic Institute of Campinas) for the municipality of Santos, SP: mean temperature, potential evapotranspiration, number of rainy days, precipitation and temperature range.

Captures and recaptures took place between March and October, since $M$. paranaguensis individuals aestivate from November to March (Miranda et al. 2015). They were quantified to estimate the population parameters according to the model of SCHWARZ \& ARNASON (1996). The fundamental parameters of this model are apparent survivorship $(\Phi)$, probability that an individual will be captured (p) and probability of an individual entering the population $(\beta)$. The model also has derived parameters, which are recruitment (B) and the estimated abundance (Population size) in each sample $\left(\mathrm{N}_{\mathrm{i}}\right)$. To assess any violations of the assumptions of mark-recapture analysis, the $\chi^{2}$ test was used.

The basic parameters are either constant or they can vary over time, and combinations thereof generate different models. To find out which model best explained the data, the Akaike information criterion with correction for small samples (AICc) (Burnham \& ANDERSon 2001) was used. Models with smaller AIC c $_{c}$ values have greater statistical support. Furthermore, to determine which model is most supported by the data the AIC Delta ( $\triangle$ AIC) was used, and Akaike weight to ascertain if the probability of the model in question is the most parsimonious (Burnham \& Anderson 2001, 2004, Johnson \& Omland 2004).

The relationship between length and weight was determined by a regression analysis, adjusting the power function using shell length as an independent variable. The resulting allometric coefficient was tested using the t-test to determine whether the growth was isometric $(b=3.00)$, positive allometric $(b>3: 00)$ or negative allometric $(b<3: 00)$. Then, the condition factor determined the adult individuals. Stepwise regressions using $\mathrm{AIC}_{\mathrm{c}}$ as variables selection criterion were conducted between environmental variables and the number of captures and the condition factor.

\section{RESULTS}

During this study there were two peaks of increased snail activity, which were represented by an increase in the number of captures. A major peak occurred from March to May, and a minor one from August to September. The number of monthly captures (Fig. 1) was lower than from December to February, when the species is dormant, and there was a decline in the number of captures during June and July. The average length of the shell of $M$. paranaguensis was $96.60 \pm 4.83$ (mean \pm SD) $\mathrm{mm}$ (minimum shell length $=70.00 \mathrm{~mm}$ and maximum shell length $=105.00)$. The mean weight of specimens was $159.21 \pm$ $35.89 \mathrm{~g}$ (minimum $=40 \mathrm{~g}$ and maximum $=226 \mathrm{~g}$ ). The resulting biometric ratio (weight $=0.0007$.Length ${ }^{2.687}, \mathrm{r}^{2}=0.8467$ ) showed negative allometry $(\mathrm{t}=4.97, \mathrm{DF}=331, \mathrm{p}<0.0001)$. The condition factor remained relatively stable as well, with a decrease from December to February (Fig. 2).
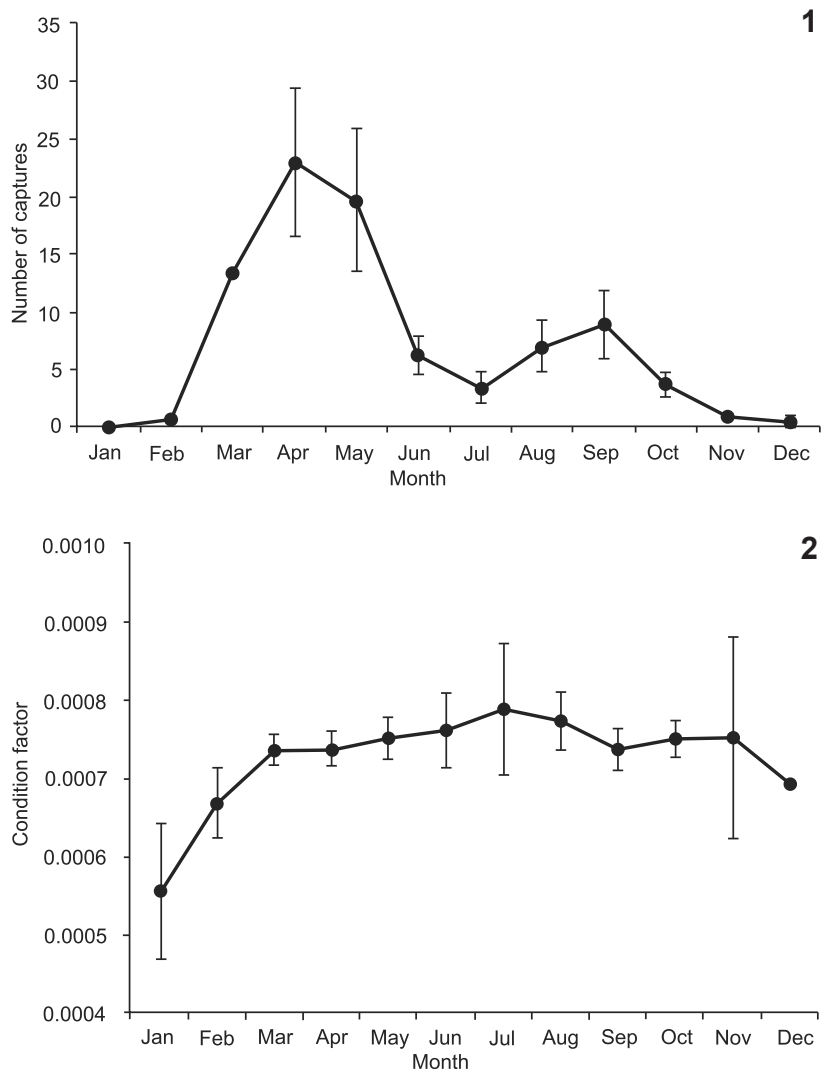

Figures 1-2. Mean number of captures (1) and condition factor (2) of Megalobulimus paranaguensis throughout the year in Parque Zoobotânico Orquidário Municipal de Santos (PZOMS).

A total of 82 adult individuals were captured. Of these, 56 were recaptured at least once (recapture rate $=0.68$ ). There were no violations of the assumptions of the mark-recapture method $\left(\chi^{2}=47.33, p=0.78, \mathrm{DF}=56\right)$. The model that best explained the data was the $\Phi() p.(t) \beta(t)$, which assumes constant survival and capture probabilities and variables entry over time (Table 1). The apparent survivorship of the population was $96.7 \%$ (CI: 94.0-97.9\%) during the four years of analysis. The capture probability showed two peaks per year: a higher peak from April to May and a shorter peak from August to September (Fig. 3), probably due to the variation of temperature and potential evapotranspiration in the area. Recruitment showed several peaks during the year, concentrated between April and August, except 
in 2009, when there was only one peak in August (Fig. 5). Abundance progressively increased in 2006 , with a tendency to relative stability after this period (Fig. 4).
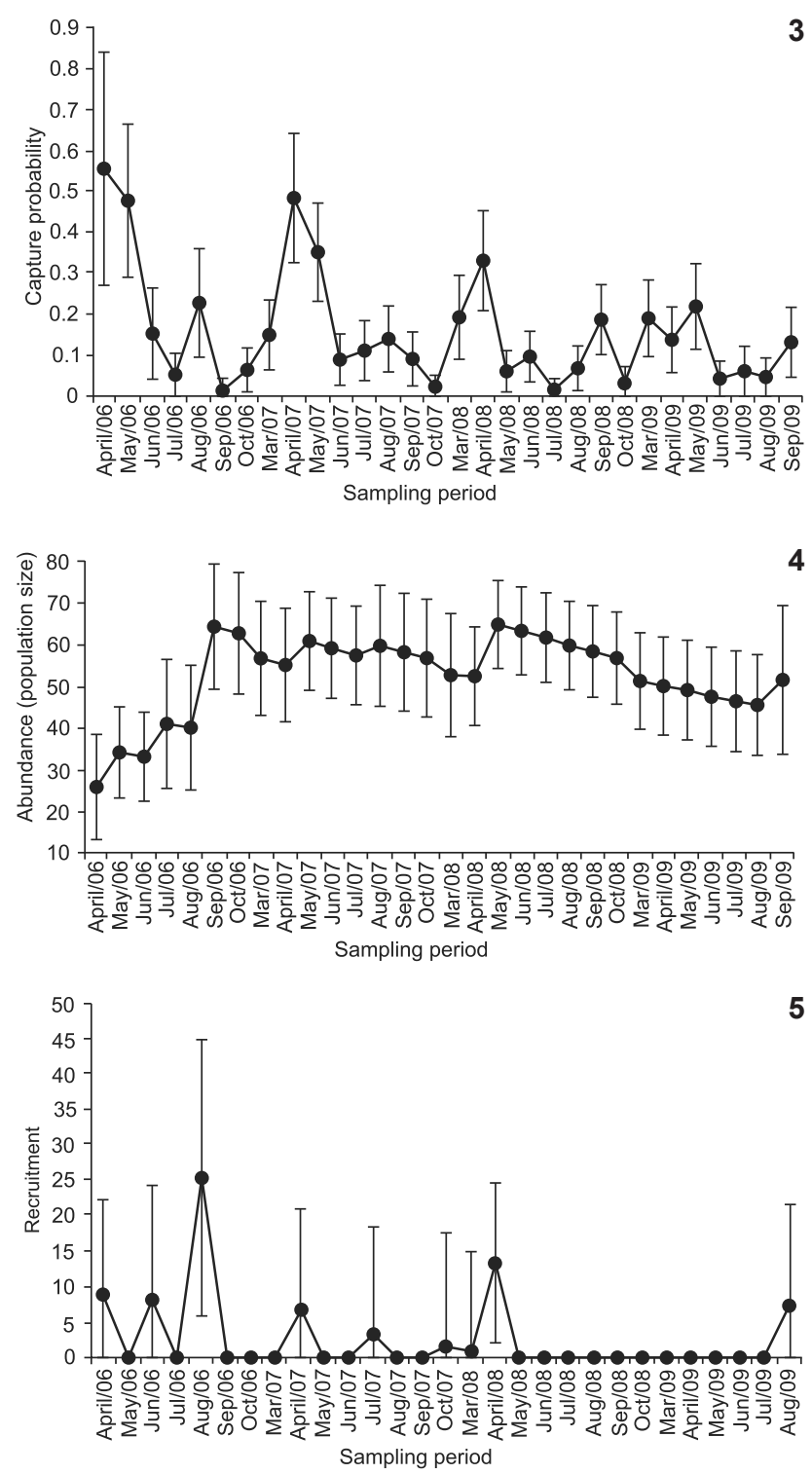

Figure 3-5. Capture probability (3), recruitment (4) and abundance (5) of Megalobulimus paranaguensis in Parque Zoobotânico Orquidário Municipal de Santos (PZOMS) during the study period.

In the results, only mean temperature, potential evapotranspiration and precipitation are shown, since they were the only variables that influenced the number of captures and condition factor (Figs. 6-8). The following variables had greater values from November to April and lower values from May to August: potential evapotranspiration and mean temperature. Potential evapotranspiration and mean temperature fluctuated significantly, while fluctuations in precipitation were more irregular, generally declining in February and peaking in July. The stepwise regression kept the variables potential evapotranspiration and precipitation. The relationship between the abundance of $M$. paranaguensis and potential evapotranspiration was negative $(\mathrm{t}=$ $3.99, \mathrm{p}<0.0001, \mathrm{~b}=-0.02)$, whereas abundance and precipitation were positively correlated $(t=1.72, p=0.08, b=0.004)$. For the condition factor, the relationship between mean temperature and abundance was negative $\left(t=2.06, p=0.04, b=2.06 \times 10^{-5}\right)$.

\section{DISCUSSION}

Megalobulimus paranaguensis has a well-defined seasonal pattern, with aestivation in the warmer months, followed by increased post-dormancy activity. This pattern is influenced by evapotranspiration, precipitation and environmental temperature. Our data show that the population of M. paranaguensis is highly resistant and has a high survival rate. The life cycle of the species is synchronized with the tropical environment, and individuals cope with heat stress by becoming numb during the hot summer months.

The extremely high survival rate of $M$. paranaguensis coupled with the recruitment peaks has resulted in an increase in the numbers of individuals over the years. Miranda et al. (2015) estimated the survival rate of M. paranaguensis at $73 \%$ in Porchat Island, São Vicente. Three factors seem to have played a role in the higher survival rate found in our study: 1) there are no predators to control the population in Parque Zoobotânico Orquidário Municipal de Santos; 2) the Orquidário has a deeper layer of plant litter, is more densely covered with vegetation and is less impacted than the Porchat Island. The latter has several areas with lower plant density and household waste in its interior; and 3) young individuals were not marked in this study. In general, the newer cohort studies have the highest mortality rate (HeLler 2001) and the exclusion of juveniles tends to overestimate the calculated survival. This has been confirmed by Romero (2004), who documented a mortality rate higher than $94 \%$ in some years in a cohort of Megalobulimus mogianensis Simone \& Leme, 1998. In his study, most individuals in captivity died before their first dormancy.

The capture probability estimated by the model followed the same tendency as the mean number of catches throughout the year. The capture probability of terrestrial snails is associated with activity (Соок 2001), which in turn is influenced by moisture, precipitation and evapotranspiration in the environment. According to the number of recruitment peaks, $M$. paranaguensis is an iteroparous species, since there is more than one posture peak during the year. This same pattern has been found in Megalobulimus abbreviatus (Bequaert, 1948) (Horn et al. 2005). Iteroparity (more than one breeding season) is relatively common among pulmonate mollusks (CALOW 1978, 

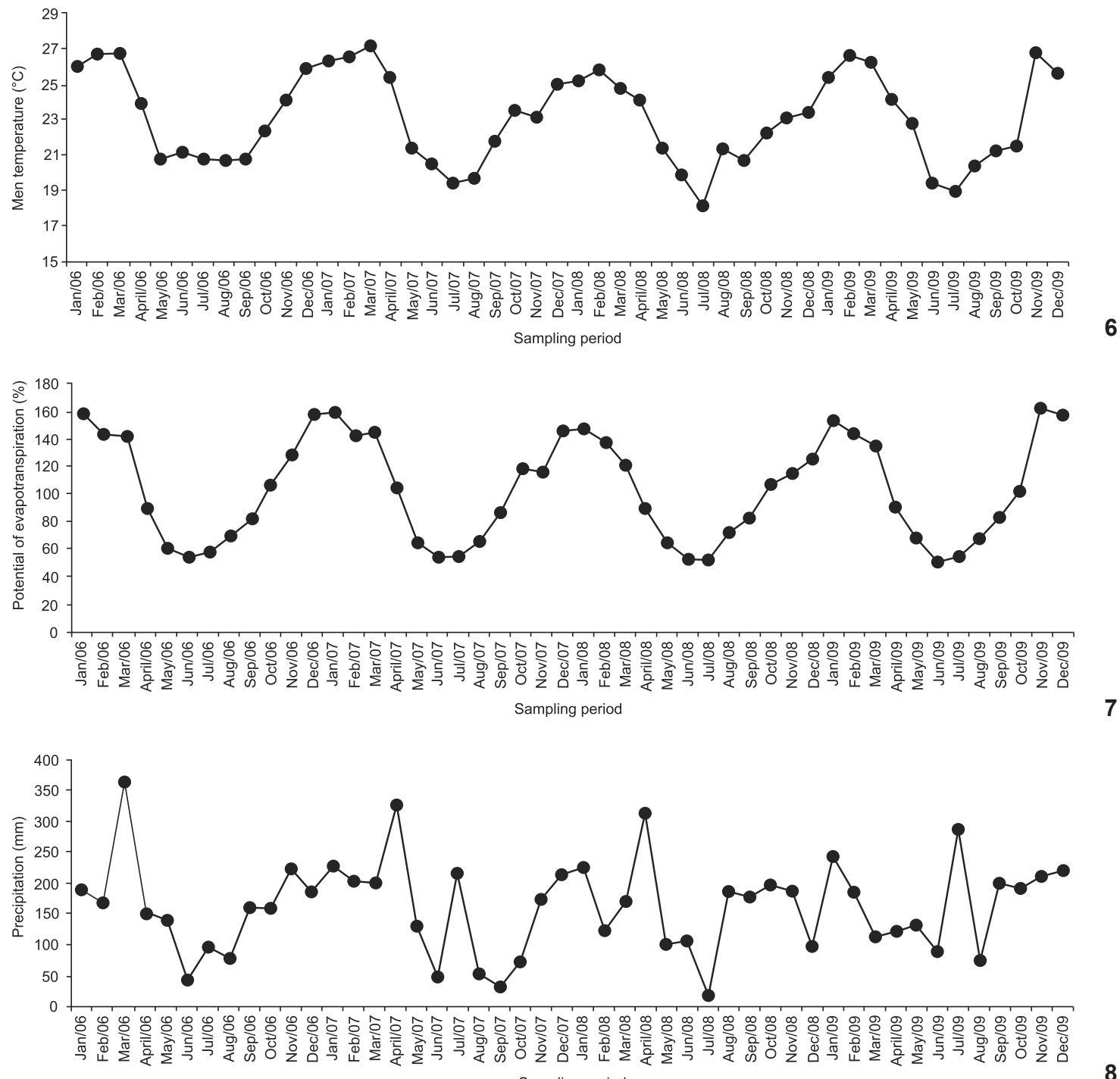

Sampling period

Figure 6-8. Mean values of temperature in ${ }^{\circ} \mathrm{C}(6)$, potential evapotranspiration in\% (7) and precipitation in mm (8) during the year in the municipality of Santos.

Table 1. Results of mark - recapture model selection of Megalobulimus paranaguensis in the Parque Zoobotânico Orquidário Municipal de Santos (PZOMS). The values of the most parsimonious model are in bold.

\begin{tabular}{|c|c|c|c|c|c|}
\hline Model & Description & $\mathrm{AlC}_{\mathrm{c}}$ & $\triangle \mathrm{AlC}_{\mathrm{c}}$ & $\mathrm{AlC}_{\mathrm{c}}$ weight & Parameters \\
\hline$\Phi() p.(t) \beta(t)$ & Constant survivorship; variable Entry and Capture probabilities & $1,140.120$ & 0.000 & 1.00 & 61 \\
\hline$\Phi() p.(.) \beta(t)$ & Constant Survivorship and Capture probability; variable Entry probability & $1,196.200$ & 56.070 & 0.00 & 32 \\
\hline$\Phi(t) p(t) \beta(t)$ & Saturated model & $1,246.690$ & 106.560 & 0.00 & 90 \\
\hline$\Phi(\mathrm{t}) \mathrm{p}(.) \beta(\mathrm{t})$ & Variable Survivorship and Entry probability; constant Capture probability & $1,263.120$ & 122.990 & 0.00 & 61 \\
\hline$\Phi(t) p(t) \beta()$. & Variable Survivorship and Capture probability; constant Entry probability & $14,844.500$ & $13,704.370$ & 0.00 & 62 \\
\hline$\Phi(t) p(t) \beta()$. & Variable survivorship and Capture probability; constant Entry probability & $38,162.693$ & $32,024.739$ & 0.00 & 33 \\
\hline$\Phi() p.(t) \beta()$. & Constant Survivorship and Entry probability; constant Capture probability & $39,012.140$ & $37,872.010$ & 0.00 & 32 \\
\hline$\Phi() p.(.) \beta()$. & Reduced model & $39,417.610$ & $38,277.490$ & 0.00 & 4 \\
\hline
\end{tabular}


LAZARIDOU-Dimitriadou 1995), and seems to be the reproductive pattern in Megalobuliminae. Recruitment also occurs in the same period as found by Miranda et al. (2015), but in their study only one recruitment peak during a period of six months was found.

Aestivation in this study was found from November to February, consistent with Miranda et al. (2015). Aestivation, a state of dormancy where there is a lot of heat or dryness (Boss 1974), is relatively common among terrestrial and freshwater mollusks (CÁCERES 1997). According to IgLESIAS et al. (1996), precipitation controls the beginning and end of dormancy in Helix aspersa Muller, 1774, whereas periods of rainless days trigger dormancy and the return of the rain marks the end of it. LaZARidou-Dimitridou \& SAunders (1986) suggested that the onset of dormancy in H. lucorum Linnaeus, 1758 is controlled by low humidity. Another factor that may also be involved in the activity cycles of $M$. paranaguensis is the presence of a possible pattern of endogenous activity. This pattern was also speculated by Lazaridou-Dimitriadou \& Saunders (1986). Therefore, aestivation in $M$. paranaguensis is caused by temperature rise and evapotranspiration between December and March, which remove moisture from the environment and cause a slowdown in snail activity. This was reflected in the condition factor of M. paranaguensis, which dropped from December to February. This drop reflects dehydration and weight loss during aestivation. Conversely, the progressive increase of this index during the months of activity show that the snails accumulated energy reserves to prepare for the state of dormancy.

The effects of environmental variables on the abundance of terrestrial mollusks are well documented in the literature. In the study of CHor et al. (2004), mathematical modeling using derived ordinary equations found that mortality in young Deroceras reticulatum (Muller, 1774) is more influenced by temperature, while recruitment rates in young individuals and the mortality rate of adults are more influenced by precipitation. Recent work by NunEs \& SANTOS (2012) showed that the variables moisture, air temperature, soil temperature and depth of plant litter influence the distribution and abundance of terrestrial gastropods in the Atlantic Forest. Snails depend on high humidity to have an active life (BAKER 1958), being sensitive to desiccation, which tends to restrict their movements (GeTz 1974). D'AVILA \& BeSSA (2005) and Dias et al. (2007) showed that substrate moisture is important for growth, reproduction, survival and resistance to desiccation in Subulina octona (Bruguière, 1792). As the evaporation removes moisture from the substrate, it decreases the number of captures, while the high precipitation tends to increase the number of catches by increasing humidity, which influences positively the activity of $M$. paranaguensis. Furthermore, according to RizzatTi \& Romero (2001), body hydration increases heart rate in M. mogianensis, and since heart rate indicates activity, precipitation is also an important factor modulating activity in M. paranaguensis. MirANDA et al. (2015), in a nearby location of this study, showed that the abundance of $M$. paranaguensis increases with increasing environmental humidity, and that humidity decreased in the period when evapotranspiration and temperature increased in this study.

\section{LITERATURE CITED}

Agudo-Padrón AI (2014) Inventario sistemático de los moluscos continentales ocurrentes en el Estado de Santa Catarina, Brasil. Bioma 2: 6-23

BAKER HB, (1958) The land snail dispersal. The Nautilus 71: 141-148.

BEqUaERT JC (1948) Monograph of the family Strophocheilidae, a Neotropical family of terrestrial mollusks. Bulletin of Museum of Comparative Zoology of Harvard 100: 1-210. Boss KJ (1974) Oblomovism in the Mollusca. Transactions of American Microscopical Society 93: 460-481.

BurNhAM KP, ANDERSON DR (2001) Kullback - Leibler information as a strong inference in ecological studies. Wildlife Research 28: 111-119. doi: 10.1071/WR99107

BURNHAM KP, ANDERSON DR (2004) Multimodel inference: Understading AIC and BIC in Model Selection. Sociological Methods \& Research 33: 261-304. doi: 10.1177/0049124104268644

CÁCERES CE (1997) Dormancy in Invertebrates. Invertebrate Biology 116: 371-383.

CaLow P (1978) The evolution of lyfe - cycle strategies in freshwater gastropods. Malacologia 17: 351-364.

Choi YH, Bohan DA, Powers SJ, Wiltshire CW, Glen DM, Semenov MA (2004) Modelling Deroceras reticulatum (Gastropoda) population dynamics based on daily temperature and rainfall. Agriculture, Ecosystems and Environment 103: 519-525. doi: 10.1016/j.agee.2003.11.012

Соок A (2001) Behavioural ecology: on doing the right thing, in the right place at the right time, p. 447-487. In: BARKER GM (Ed.) The biology of terrestrial molluscs. Wallingford, CABI Publishing, XIV+558p.

D'Ávila S, Bessa ECA (2005) Influência de diferentes substratos e umidade sobre o crescimento e o número de ovos produzidos por Subulina octona (Bruguière) (Mollusca, Subulinidae), sob condições de laboratório. Zoologia 22: 349-353. doi: 10.1590/S0101-81752005000200008

Dias RJP, Bessa ECA, D'Ávila S (2007) Influence on Desication Resistence Capacity in Subulina octona (Mollusca, Subulinidae). Brazilian Archives of Biology and Technology 50: 137-139. doi: 10.1590/S1516-89132007000100016

Eston MR, Menezes GV, Antunes AZ, Santos ASR, Santos AMR (2006) Espécie invasora em unidade de conservação: Achatina fulica (Bowdich, 1822) no Parque Estadual Carlos Botelho Sete Barras, SP, Brasil. Revista do Instituto Florestal 18: 173-179.

Fontenelle JH, Miranda MS (2012) The use of outer lip in age estimation of Megalobulimus paranaguensis (Gastropoda, Pulmonata). Strombus 19: 15-22. 
Getz LL (1974) Species diversity of terrestrial snails in the great Smoky Montains. The Nautilus 88: 6-9.

Heller J (2001) Life History Strategies, p. 413-445. In: Barker GM (Ed.) The biology of terrestrial molluscs. CABI Wallingford, Publishing, XIV+558p.

Horn ACM, Achaval M, Zancan DM (2005) The annual reproductive cycle of the snail Megalobulimus abbreviatus (Bequaert, 1948) (Gastropoda, Pulmonata). Brazilian Journal of Biology 65: 459-467. doi: 10.1590/S151969842005000300011

Iglesias J, Santos M, Castillejo J (1996) Annual activity cycles of the land snail Helix aspersa Muller in natural populations of north-western Spain. Journal of Molluscan Studies 62: 495-505.

Johnson JB, OMLAnd KS (2004) Model selection in ecology and evolution. Trends in ecology and evolution 19: 101-108. doi:10.1016/j.tree.2003.10.013

Lazaridou-Dimitriadou M (1995) The life cycle, demographic analysis, growth and secondary production of the snail Helicella (Xerothracia) pappi (Schutt, 1962) (Gastropoda, Pulmonata) in E. Macedonia (Greece). Malacologia 37: 1-11.

Lazaridou-Dimitriadou M, Saunders DS (1986) The influence of humity, photoperiod and temperature on the dormancy and activity of Helix lucorum L. (Gastropoda, Pulmonata). Journal of Molluscan Studies 52: 180-189.

LEME JLM (1973) Anatomy and systematics of neotropical Strophocheiloidea (Gastropoda, Pulmonata) with the description of a new family. Arquivos de Zoologia 23: 295-337.
Miranda MS, Fontenelle JH, Pecora IL (2015) Population structure of a native and na alien species of snail in an urban fragment of Atlantic Rainforest. Journal of Natural History 49: 19-35. doi: 10.1080/00222933.2014.930756

Morretes FL (1954) Sôbre Megalobulimus paranaguensis Pilsbry \& Ihering. Arquivos do Museu Paranaense 10: 343-344.

Nunes GKM, SANTOS SB (2012) Environmental factors affecting the distribution of land snails in the Atlantic Rain Forest of Ilha Grande, Angra dos Reis, RJ, Brazil. Brazilian Journal of Biology 72: 79-86. doi: 10.1590/S1519-69842012000100010

Rizzatti ACS, Romero SMB (2001) Heart rate and body weight alterations in juvenile specimens of the tropical land snail Megalobulimus sanctipauli during dormancy. Brazilian Journal of Medical and Biological Research 34: 959-967. doi: 10.1590/S0100-879X2001000700015

Romero SMB (2004) Growth of Megalobulimus mogianensis (Gastropda: Megalobulimidae) raised in the laboratory from hatching to adulthood. American Malacological Bulletin 18: $79-85$.

Schwarz CJ, Arnason AN (1996) A general methodology for the analysis of capture-recapture experiments in open populations. Biometrics 52: 860-873.

SIMONE LRL (2006) Land and freshwater molluscs of Brazil. São Paulo, EGB, FAPESP, 390p.

Sobreira HB, Molina FB (2002) Observações preliminares sobre a biologia reprodutiva de Megalobulimus gummatus (Mollusca, Megalobulimidae) em laboratório. Arquivos do Instituto Biológico 69: 139-141.

Submitted: 29 May 2015

Received in revised form: 7 October 2015

Accepted: 15 November 2015

Editorial responsibility: Walter A.P. Boeger

ZOOLOGIA 32 (6): 463-468, December 2015 